\title{
Studies of the Dry Surface Layer in a Sand Dune Field (2) Effects of Soil Temperature Gradients on the Water Content Profiles in the Dry Surface Layer
}

\author{
Tetsuo Kobayashi*, Akiyoshi Matsuda** and Makio KamichiKA** \\ ${ }^{*}$ Faculty of Agriculture, Shimane University, Matsue 690$)$ \\ ** Sand Dune Research Institute, Faculty of Agriculture, \\ Tottori University, Tottori 680
}

\begin{abstract}
The behavior of soil water in a dry surface layer of sand developing under temperature gradients was discussed and a model for the layer under nonisothermal steady conditions was formulated by extending our isothermal steady model (Kobayashi et al., 1986). To bear out the nonisothermal steady model, the effects of temperature gradient on the water content profiles in the layer were examined by comparing the difference in shape between the profiles obtained using our isothermal and nonisothermal models with the observed one; the calculated difference in shape was found to be in qualitative agreement with the observed one.

A significant reason why the dry surface layer can be distinguished definitely from the moist underlayer during the developing process is the presence of a steep temperature gradient in the surface layer. With an increase in the gradient of temperature across the dry surface layer the gradient of water content in the lower part of the layer becomes steeper, that is, the moisture contrast between the dry surface layer and the moist underlayer becomes greater.
\end{abstract}

\section{Introduction}

When a dry surface layer grows in a sand dune field, a steep temperature gradient develops across the layer, that is, the soil temperature decreases rapidly with depth in the layer. It was shown by an experiment that the dry surface layer of sand, or the "dry sand layer", develops also under the condition of uniform temperature (Kobayashi et al., 1986); however, there are two features which are different from those in the presence of temperature gradients:

(A) The moisture contrast between the dry surface layer and the moist underlayer under isothermal conditions is not so great as that under most field conditions, that is, under temperature gradients.

(B) The developing rate of the dry surface layer under isothermal conditions is smaller than that under temperature gradients.

Read at the Western Three Chapters Joint Meeting on November 21, 1986

Received 13 March, 1987

* Present Address: Faculty of Agriculture, Kyushu University, Fukuoka 812
Although the feature (B) depends on the water distribution in the moist underlayer, the major cause of these differences seems to be the gradient of temperature developing across the layer.

In this paper, the behavior of soil water in a dry sand layer growing under temperature gradients is discussed. Further, by extending our model for a dry sand layer under isothermal steady conditions (Kobayashi et al., 1986), a model for the layer under nonisothermal steady conditions is formulated. The direct experimental verification of this model is difficult, thus we focus attention on the effects of temperature gradients on the water content profiles. The effects obtained using our isothermal and nonisothermal models are compared with the observed ones.

\section{Soil water movement under temperature gradients}

Soil water moves in two phases, liquid and vapor. The effects of temperature gradients on the water movement, however, are more significant in the vapor phase than in the liquid phase. The 
principal phenomena which occur when temperature gradients develop in soils are as follows:

(a) The vapor density in soils increases with the soil temperature.

(b) The vapor moves by thermal diffusion from the region of higher temperature to the region of lower temperature in soils.

Extensive studies for the movement of soil water under temperature gradients have been made (Philip and de Vries, 1957; Suzuki, 1962; Miyazaki, 1976; Shinjo, 1977). However, in these studies the phenomenon (b) has been neglected and only the phenomenon (a) has been considered, that cannot unconditionally be permitted (Kobayashi et al., 1985).

Another feature which cannot be disregarded when analyzing phenomenologically the soil water movement under temperature gradients is;

(c) Coefficients of transport equations (e.g., diffusivity) vary with temperature; therefore, they vary with the location in soils.

If the vapor in a pore is in equilibrium uniquely with the liquid water in the same pore, the vapor density $\rho_{v}\left(\mathrm{~g} \mathrm{~cm}^{-3}\right)$ can be expressed as

$$
\rho_{v}=\rho_{s} \exp \left(\psi g / R_{w} T\right),
$$

where $\rho_{s}$ is the saturation vapor density at a temperature $T(\mathrm{~K}) ; \phi$ the matric potential of soil water $(\mathrm{cm}), R_{w}$ the gas constant of water vapor (erg g ${ }^{-1} \mathrm{~K}^{-1}$ ), $g$ the gravitational acceleration $\left(\mathrm{cm} \mathrm{s}^{-2}\right)$. The gradient of vapor density is, therefore,

$$
\begin{aligned}
\nabla \rho_{v}= & \rho_{v}\left\{\left(\frac{1}{\rho_{s}} \frac{\mathrm{d} \rho_{s}}{\mathrm{~d} T}-\frac{\phi g}{R_{w} T^{2}}+\frac{g}{R_{w} T} \frac{\partial \psi}{\partial T}\right) \nabla T\right. \\
& \left.+\frac{g}{R_{w} T} \frac{\partial \phi}{\partial \theta} \nabla \theta\right\}
\end{aligned}
$$

where $\theta$ is the volumetric water content $\left(\mathrm{cm}^{3}\right.$ $\mathrm{cm}^{-3}$ ).

Estimating the order of magnitude of each term and neglecting the small terms, we can simplify Eq. (2), for the range $\phi>-10^{6} \mathrm{~cm}$ (i.e., $p F<6$ ), as

$$
\nabla \rho_{v}=\rho_{v}\left\{\frac{1}{\rho_{s}} \frac{\mathrm{d} \rho_{s}}{\mathrm{~d} T} \nabla T+\frac{g}{R_{w} T} \frac{\partial \phi}{\partial \theta} \nabla \theta\right\}
$$

(Nakano and Miyazaki, 1976). This condition is satisfied in a dry sand layer.

We shall now examine the order of magnitude

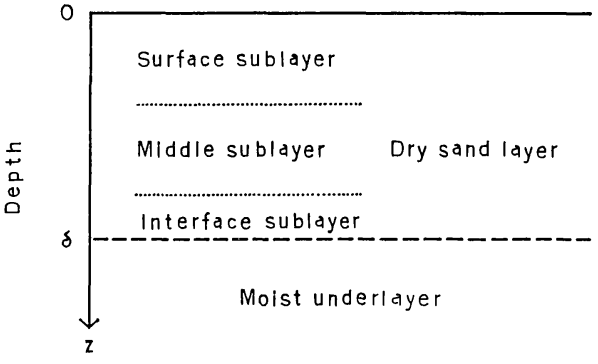

Fig. 1. Subdivision of a dry sand layer for an order-of-magnitude analysis.

of the two terms on the right side of Eq. (3). Let us divide a dry sand layer into three parts, that is, the surface sublayer, the middle sublayer, and the interface sublayer (Fig. 1). First we take up the middle sublayer.

When a dry sand layer is growing in a field in the summer season, the average temperature in the middle sublayer is about $40^{\circ} \mathrm{C}(313 \mathrm{~K})$, then we have

$$
\left(1 / \rho_{s}\right)\left(\mathrm{d} \rho_{s} / \mathrm{d} T\right) \sim 0.05 \mathrm{~K}^{-1},
$$

where the symbol " " is read "is approximately". Thus, suppose $\nabla T$ to be about $3 \mathrm{~K} \mathrm{~cm}^{-1}$, we get

$$
\left(1 / \rho_{s}\right)\left(\mathrm{d} \rho_{s} / \mathrm{d} T\right) \nabla T \sim 0.1 \mathrm{~cm}^{-1} .
$$

Since the average volumetric water content in the middle sublayer is less than 0.01 , we have

$$
\partial \phi / \partial \theta \sim 10^{8} \mathrm{~cm}
$$

(Kobayashi et al., 1986). Thus, suppose $\nabla \theta$ to be about $0.002 \mathrm{~cm}^{-1}$, we get

$$
\left(g / R_{w} T\right)(\partial \psi / \partial \theta) \nabla \theta \sim 0.1 \mathrm{~cm}^{-1} .
$$

Consequently, we obtain the result that the two terms on the right side of Eq. (3) are of the same order in the middle sublayer.

In the surface sublayer of a dry sand layer, the temperature is higher and the water content is smaller than those in the middle sublayer. This results in $\left(1 / \rho_{s}\right)\left(\mathrm{d} \rho_{s} / \mathrm{d} T\right)$ being smaller and $\left(g / R_{w} T\right)(\partial \phi / \partial \theta)$ being larger in the surface sublayer. The numerical value of the latter at $\theta=0.004$ is an order of magnitude larger than that at $\theta=0.01$. If the effect of an additional vapor transfer caused by the turbulent air flow over the top surface is excluded, the gradient of water content in the surface sublayer seems almost the 
same as that in the middle sublayer (Kobayashi et al., 1986). Further, although the gradient of temperature across the surface sublayer is a little greater than that across the middle sublayer, the increase in $\nabla T$ may be expected to cancel out with the decrease in $\left(1 / \rho_{s}\right)\left(\mathrm{d} \rho_{s} / \mathrm{d} T\right)$. Thus it seems reasonable to assume that the first term on the right side of Eq. (3) is much less than the second term in the surface sublayer.

In the interface sublayer of a dry sand layer, the gradient of water content is very large, while the gradient of temperature is small. Thus, it may be supposed that the gradient of vapor density in this sublayer is controlled mainly, as in the surface sublayer, by the gradient of water content. We may also assume that the "series-parallel flow through liquid islands" is negligible, since the region where the liquid islands exist can be considered as belonging to the moist underlayer (Philip and de Vries, 1957).

We postulate, therefore, that the upward vapor flux through a whole dry sand layer during the developing process is controlled mostly by the gradient of water content and the feature (c) presented previously. This postulation is not necessarily evident and ought to be corroborated by experiment. The gradient of soil temperature which points upward must resist the upward vapor movement in the layer, but this effect should become weaker with increasing temperature and with decreasing water content.

\section{A nonisothermal steady model for a dry sand layer}

As reported in the previous paper, we formulated a model for a dry sand layer under isothermal steady conditions (Kobayashi et al., 1986). In this model, it is assumed that the water movement in the layer is exclusively in the vapor phase and the upward vapor flux in the layer $q\left(\mathrm{~cm} \mathrm{~s}^{-1}\right)$ is given by

$$
q=D(\theta, T) \mathrm{d} \theta / \mathrm{d} z,
$$

where $z$ is the depth (cm) (Fig. 1), $D(\theta, T)$ is the water vapor diffusivity $\left(\mathrm{cm}^{2} \mathrm{~s}^{-1}\right)$, which is a function of the water content and the temperature in the layer. Since the state is assumed to be steady, the temperature at a certain depth remains constant, and hence the diffusivity is a function of the water content and the depth. Thus we can construct a simple nonisothermal steady model for a dry sand layer by extending our isothermal steady model to take into account the postulation presented in the previous section.

Let us assume that the temperature $T$ in a dry sand layer varies with the depth $z$ according to a linear relation

$$
T=\alpha_{z}+T_{0}
$$

where $\alpha$ and $T_{0}$ are constants. Although the theoretical form of $D(\theta, T)$ is very complicated, an approximation of the function was empirically obtained for the Tottori Dune sand, which is

$D(\theta, T)=\exp (0.0649 T-34.88) \theta^{2}(\theta-2.4)^{6}$

for $273 \mathrm{~K} \leqq T \leqq 333 \mathrm{~K}$, where $\theta$ is expressed in percent (henceforth expressed in percent) (Kobayashi et al., 1986). In a steady state, that is, when $q$ is a constant, substituting Eqs. (7) and (8) in Eq. (6) and integrating the resultant equation from $z=0$ at the surface of a dry sand layer to $z=z$ gives

$$
\begin{aligned}
& q \exp \left(-0.0649 T_{0}+34.88\right) \int_{0}^{z} \exp (-0.0649 \alpha z) \mathrm{d} z \\
& \quad=\int_{\theta_{0}}^{\theta} \theta^{2}(\theta-2.4)^{6} \mathrm{~d} \theta
\end{aligned}
$$

Thus,

$$
\begin{aligned}
z= & -\ln \left[1-0.0649 \alpha \exp \left(0.0649 T_{0}-34.88\right)\right. \\
& \left.\times\left\{f(\theta)-f\left(\theta_{0}\right)\right\} / q\right] / 0.0649 \alpha
\end{aligned}
$$

where

$$
\begin{aligned}
f(\theta) \equiv & (1 / 9) \theta^{9}-1.8 \theta^{8}+(86.4 / 7) \theta^{7}-46.08 \theta^{6} \\
& +99.53 \theta^{5}-119.44 \theta^{4}+63.70 \theta^{3}, \quad(10)
\end{aligned}
$$

and $\theta_{0}$ is the value of $\theta$ at the surface. Equation (9) gives the water content profile in the dry sand layer of the Tottori Dune sand. Similar expressions could also be written for other kinds of dry sand layers. The value of $z$ corresponding to $f(\theta)=10.3$ $(\theta=1.5 \sim 2 \%)$ is the thickness of the dry sand layer $\delta(\mathrm{cm})$ (Fig. 1) (Kobayashi et al., 1986).

\section{Results and discussion}

Figure 2 shows a comparison of the water content profiles in surface layers under isothermal and nonisothermal conditions. The solid curve represents the profile observed at 15:00 on August 14, 1985 in the bare sand field of Sand Dune Research Institute, Tottori University, the tem- 
Volumetric water content $(\%)$

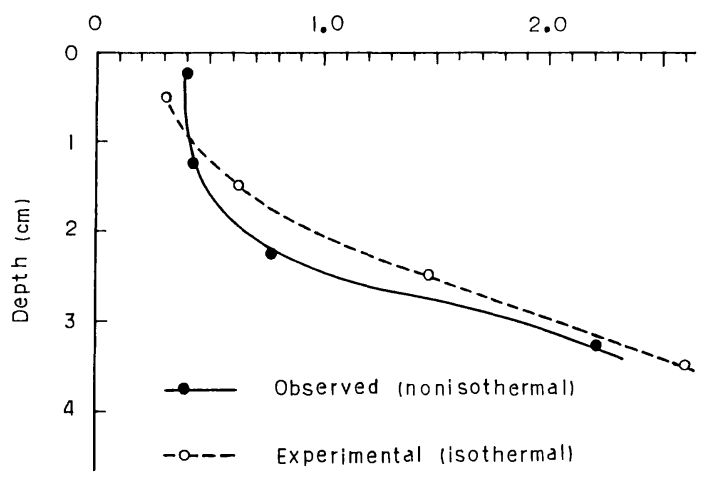

Fig. 2. Comparison of water content profiles under isothermal and nonisothermal conditions. The solid curve represents the profile observed at 15:00 on August 14, 1985 in the Tottori Sand Dune ( $325 \mathrm{~K}$ at the surface); the dashed curve the profile in a sand column (consisting of the Tottori Dune sand) placed in a constant temperature chamber $(323 \mathrm{~K})$.

perature at the surface and the gradient of temperature across the dry surface layer being $325 \mathrm{~K}$ and $-3 \sim-5 \mathrm{~K} \mathrm{~cm}^{-1}$, respectively. The dashed curve represents the profile in a sand column (consisting of the Tottori Dune sand) placed in a chamber where the temperature was maintained at $323 \mathrm{~K}$; the evaporation rate from the top surface was about $3 \mathrm{~mm}^{\text {day }}{ }^{-1}$ (Kobayashi et al., 1986). Although the thickness of the dry sand layer under isothermal conditions is much the same as that under nonisothermal conditions, the water content profile under isothermal conditions differs distinctly from that under temperature gradients.

Figure 3 shows the profiles obtained using our isothermal and nonisothermal models for a dry sand layer. The solid curve represents the profile obtained from Equation (9) by letting $\alpha=-6$ $\mathrm{K} \mathrm{cm}^{-1}, T_{0}=333 \mathrm{~K}, \theta_{0}=0.4 \%$, and $q=2 \mathrm{~mm} \mathrm{day}^{-1}$ $\left(=2.31 \times 10^{-6} \mathrm{~cm} \mathrm{~s}^{-1}\right)$. The dashed curve represents the profile obtained with our isothermal model by letting the temperature be $322.5 \mathrm{~K}, \theta_{0}$ and $q$ being the same as those for the nonisothermal conditions above.

Comparison of Figs. 2 and 3 shows that there is an interesting similarity between the observed difference in the form of the profile curves under
Volumetric water content $1 \% 1$

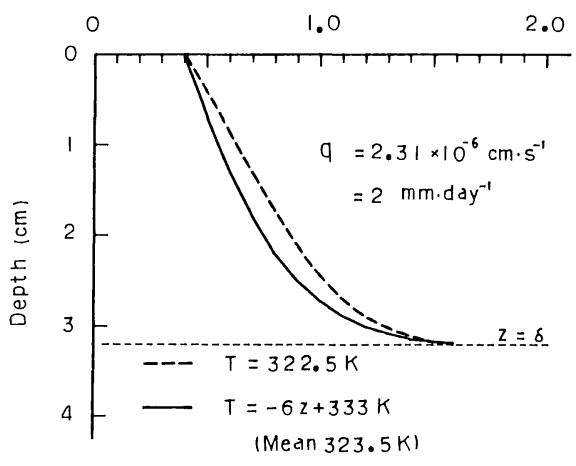

Fig. 3. Comparison of the water content profiles obtained using our isothermal and nonisothermal steady models for a dry sand layer. The solid curve represents a nonisothermal profile and the dashed curve an isothermal profile, the conditions being shown on the figure.

the two conditions and the calculated one. Although the profiles obtained using our models do not completely agree with observed ones [the causes of the disagreement were already discussed in Kobayashi et al. (1986)], the effects of temperature gradient on the profile obtained from our models agree qualitatively with the experimental findings; that is, the presence of the gradient of temperature across a dry sand layer makes the gradient of water content in the lower part of the layer steeper. This is an evidence which supports our postulation assumed in this paper, and hence we may conclude that the feature (c) presented previously is the most important point when the soil water movement in a dry sand layer under temperature gradients is phenomenologically analyzed.

Suppose that our nonisothermal steady model yields the essential features of a dry sand layer under temperature gradients, then we can see the effects of temperature gradients on the thickness of the layer, or on the evaporation rate. Figure 4 gives the relation between the thickness and the gradient of temperature across the layer. A curve shows how the thickness is related to the gradient of temperature when the average temperature in the layer is kept at the value given at the end of the curve. The assumed evaporation rate and the value of $\theta$ at the surface are $2 \mathrm{~mm} \mathrm{day}^{-1}$ and 


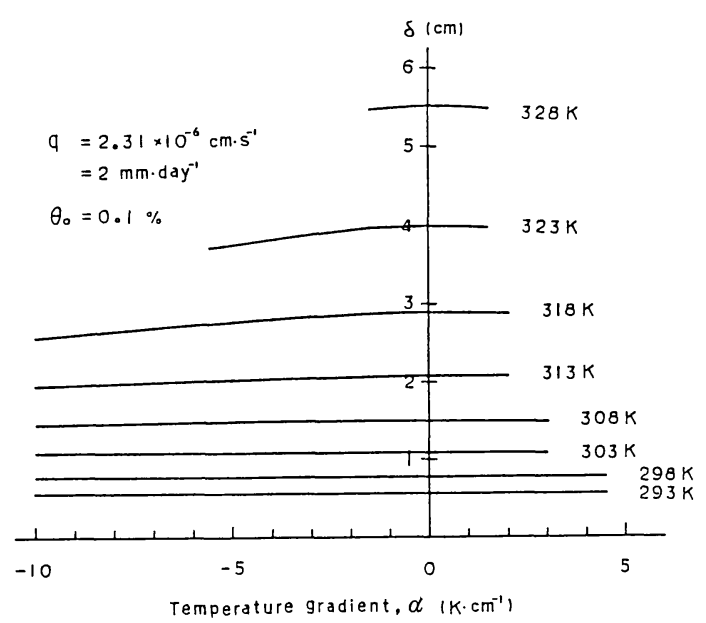

Fig. 4. Relation between the thickness of a dry sand layer $\delta$ and the gradient of temperature across the layer obtained using our nonisothermal steady model for a dry sand layer.

A curve shows the relation under the condition of constant average temperature. The curve parameters represent the average temperature in the layer.

$0.1 \%$, respectively. These curves reveal that the thickness of the layer remains nearly constant when the average temperature, the evaporation rate and the surface water content are unchanged, independent of the gradient of temperature across the layer. Thus, the evaporation rate will almost remain the same so long as the average temperature in the layer, the depth of the layer and the surface water content remain constant, no matter what the gradient of temperature across the layer might be.

Direct verification of these results by experiment, however, is so difficult that it is necessary to test many results from the model against experimental evidence before a final conclusion can be drawn. An experimental investigation into the results above will be reported in the next paper.

\section{Conclusions}

The behavior of soil water is much complicated by the presence of temperature gradients. We have postulated in this paper that under dry and high temperature conditions such as occur in a dry sand layer, the gradient of vapor density in soils is mainly controlled by the moisture distribution, and the effects of temperature gradients on the vapor movement can be included in the temperature dependence of the vapor diffusivity. Although the direct experimental verification of the postulation is difficult, it has been shown that the effects of temperature gradients on the water content profiles in a dry sand layer can be explained qualitatively by the postulation above. As a result, it has turned out that the presence of temperature gradients across a dry sand layer, as well as the physical properties of sand, is a significant reason why the layer is distinguished definitely from the moist underlayer by the different shades (Fritton et al., 1970).

With an increase in the gradient of temperature across a dry sand layer the gradient of water content in the lower part of the layer becomes steeper, that is, the moisture contrast between the dry surface layer and the moist underlayer becomes greater. With increasing moisture contrast between the two layers, the upward water flux across the interface also increases. Thus the developing rate of a dry sand layer must depend on the gradient of temperature across the layer. It can be shown by experiment that the developing rate under temperature gradients is much greater than that under isothermal conditions, which is compatible with the prediction above.

\section{References}

Fritton, D. D., Kirkham, D. and Shaw, R. H., 1970: Soil water evaporation, isothermal diffusion, and heat and water transfer, Soil Sci. Soc. Amer. Proc., 34, 183-189.

Kobayashi, T., Matsuda, A. and Kamichika, M., 1985: Basic theories of water vapor transport in soils under temperature gradients, J. Agr. Met. Kyushu, 21, 21-26 (in Japanese).

Kobayashi, T., Matsuda, A., Kamichika, M. and Sato, T., 1986: Studies of the dry surface layer in a sand dune field (1) Modeling of the dry surface layer of sand under isothermal steady conditions, J. Agr. Met., 42, 113-118.

Miyazaki, T., 1976: Condensation and movement of water vapor in sand under temperature gradient, Trans. JSIDRE, 61, 1-8.*

Nakano, M. and Miyazaki, T., 1979: The diffusion and nonequilibrium thermodynamics equations of water vapor in soils under temperature gradients, Soil Sci., 128, 184-188.

Philip, J. R. and de Vries, D. A., 1957: Moisture movement in porous materials under tempera- 
ture gradients. Trans. Amer. Geophy. Union, 38, 222-232.

Shinjo, A., 1977: Movement of water in a soil under thermal gradient, Trans. JSIDRE, 69, $8-12$. $^{*}$
Suzuki, Y., 1962: Movement of soil moisture under the temperature gradients, J. Agr. Met., 18, 98-104.*

* written in Japanese with English summary.

\title{
砂丘地の乾砂層に関する研究
}

（2）乾砂層内の含水量プロフィールに及ぼす 地温勾配の影響

\author{
小林哲夫* 松田昭美 $^{* *}$ 神近牧男 ${ }^{* *}$ \\ ${ }^{*}$ 島根大学農学部 \\ **鳥取大学農学部附属砂丘利用研究施設)
}

要 約

発達中の乾砂層内では急激な温度勾配が形成される。 すなわち，地温は地表面近くで著しく上昇する。そのよ うな状態下での土壤水分の挙動について検討し, 前報 (Kobayashi et al., 1986) で示した乾砂層の等温定常 モデルを拡張して非等温定常モデルを構成した。また, 本モデルの信頼性を確かめるために, 層内の含水量プロ フィールに対する温度勾配の影響に着目し, 上記両モデ ルから得られる等温, 非等温プロフィールの形状の違い を実測プロフィールの場合と比較した。その結果, 両者 は定性的に一致し, 発達過程にある乾砂層内の温度勾配
の存在は乾砂層が湿潤下層と色あいによってはっきり識 別される主な理由の一つであるととが明らかになった。 乾砂層内の温度勾配か増すと層内下部の含水量勾配屯大 きくなり，湿潤下層との水分コントラストが明りょうに なるのである。

両層の水分コントラストが大きくなればそれらの境界 を横切る水分上昇フラックスあ增大するはずであるから, 乾砂層の発達速度むまた層内の温度勾配と共に大きくな ると考えられる。乙れは経験的事実と一致する。

*現：九州大学農学部 